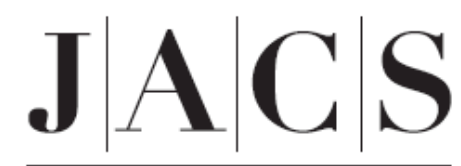

A R T I C L E S

\title{
A Redox-Driven Multicomponent Molecular Shuttle
}

\author{
Sourav Saha, ${ }^{\dagger}$ Amar H. Flood, ${ }^{\ddagger}$ J. Fraser Stoddart, ${ }^{*}$
}

Stefania Impellizzeri, ${ }^{\S}$ Serena Silvi, ${ }^{\S}$ Margherita Venturi, ${ }^{\S}$ and Alberto Credi $* \$$

Contribution from the $\uparrow$ California NanoSystems Institute and the Department of Chemistry and

Biochemistry, University of California, Los Angeles, CA 90095, $\neq$ Department of Chemistry,

Indiana University, Bloomington, IN 47405 and § Dipartimento di Chimica “G. Ciamician”,

Università di Bologna, via Selmi 2, 40126 Bologna, Italy

\section{SUPPORTING INFORMATION}

\section{REVISED VERSION}

\section{Correspondence Address}

Prof J Fraser Stoddart

California NanoSystems Institute

Department of Chemistry and Biochemistry

University of California, Los Angeles

405 Hilgard Avenue

Los Angeles, California, 90095-1569 (USA)

TEL: (+1) 310-206-7078

FAX: (+1) 310-206-1843

EMAIL: stoddart@chem.ucla.edu, alberto.credi@unibo.it 


\section{Experimental Section}

General Methods. Starting materials and reagents were purchased from Aldrich and used as received. The $\mathrm{P}-\mathrm{C}_{60}$ dyad ${ }^{\mathrm{S} 1} \mathbf{3}$, and compounds $5,{ }^{\mathrm{S} 2} \mathbf{7},{ }^{\mathrm{S} 3} \mathbf{1 0},{ }^{\mathrm{S4}} \mathbf{1 3},{ }^{\mathrm{S} 5}$ and $\alpha, \alpha^{\prime}-[1,4-$ phenylene-bis-(methylene)]bis(4,4'-bipyridinium) bis(hexafluorophosphate $)^{\mathrm{S6}} \quad \mathbf{1 5} \cdot 2 \mathrm{PF}_{6}$ were prepared as described in the literature. All reactions were performed under an argon atmosphere and in dry solvents unless otherwise noted. Analytical thin-layer chromatography (TLC) was performed on aluminum sheets, precoated with silica gel 60$\mathrm{F}_{254}$ (Merck 5554). Flash chromatography was performed with silica gel 60 (Silicycle). The rotaxane $\mathbf{1}^{4+}$, the $\mathrm{P}-\mathrm{C}_{60}$ dyad $\mathbf{3}$, and the tetrad $\mathbf{2}$ are all mixtures of several diastereoisomers. No attempt was made to isolate them. ${ }^{1} \mathrm{H}$ NMR Spectra were recorded on either a Bruker ARX $400 \mathrm{MHz}$, a Bruker Avance $500 \mathrm{MHz}$, or a Bruker Avance 600 $\mathrm{MHz}$ spectrometer at ambient temperature in appropriate deuterated solvents using tetramethylsilane as an internal reference. High-resolution matrix-assisted-laserdesorption-ionization mass spectra (HR-MALDI-MS) were recorded on an IonSpec Ultima 7.0T FT-ICR MALDI mass spectrometer using dihydroxybenzoic acid (DHB) or anthracene as a matrix and A19L oligopeptide (APPPDPDPGP EIKAKRLNL, monoisotopic mass $=2024.1)$ as an external calibration. High-resolution electrospray ionization mass spectra (HR-ESI-MS) were obtained using an IonSpec Ultima 7.0T FTICR ESI mass spectrometer. Fast atom bombardment mass spectra (FAB-MS) were recorded using a ZAB-SE mass spectrometer, equipped with a krypton ion beam, using an $m$-nitrobenzyl alcohol matrix. UV-Vis spectra were recorded on a Varian 100-Bio UVVis spectrophotometer.

6. A mixture of 2,6-diisopropylphenol $(1 \mathrm{~g}, 5.6 \mathrm{mmol})$, the bistosylate ${ }^{\mathrm{S} 2} \mathbf{5}(4.7 \mathrm{~g}, 11.2$ mmol), anhydrous $\mathrm{K}_{2} \mathrm{CO}_{3}$ (2.35 g, excess), and [18]crown-6 (0.25 g, catalytic) in MeCN $(200 \mathrm{~mL})$ was heated under reflux for $15 \mathrm{~h}$. The solvent was removed and hexanes (100 $\mathrm{mL}$ ) were added to the reaction mixture. After filtering off the inorganic salts, the solvent was removed from the filtrate. The residue was purified subsequently by column chromatography $\left(\mathrm{SiO}_{2}: \mathrm{CH}_{2} \mathrm{Cl}_{2} /\right.$ hexanes, 9:1) to obtain the tosylate $6(2 \mathrm{~g}, 85 \%)$ as a 
colorless oil. ${ }^{1} \mathrm{H}$ NMR (500 MHz, $\left.\mathrm{CD}_{2} \mathrm{Cl}_{2}\right): \delta=1.18(\mathrm{~d}, J=7 \mathrm{~Hz}, 12 \mathrm{H}), 2.44(\mathrm{~s}, 3 \mathrm{H}), 3.32$ (sept, $J=5 \mathrm{~Hz}, 2 \mathrm{H}$ ), 3.76 (t, $J=5 \mathrm{~Hz}, 4 \mathrm{H}$ ), 3.83 (t, $J=5 \mathrm{~Hz}, 2 \mathrm{H}), 4.17$ (t, $J=5 \mathrm{~Hz}, 2 \mathrm{H}$ ), $7.08(\mathrm{~d}, J=5 \mathrm{~Hz}, 3 \mathrm{H}), 7.36(\mathrm{~d}, J=8 \mathrm{~Hz}, 2 \mathrm{H}), 7.79 \mathrm{ppm}(\mathrm{d}, J=8 \mathrm{~Hz}, 2 \mathrm{H})$. MS (HRMALDI) $m / z 443.1873[M+\mathrm{Na}]^{+}$(DHB matrix).

8. This compound was prepared using a modification of the literature procedure. ${ }^{\mathrm{S} 4} \mathrm{~A}$ mixture of the tosylate $6(2 \mathrm{~g}, 4.8 \mathrm{mmol})$, the dioxynaphthalene derivative ${ }^{\mathrm{s} 3} \mathbf{7}(0.9 \mathrm{~g}, 3.6$ mmol), anhydrous $\mathrm{K}_{2} \mathrm{CO}_{3}$ (2 g, excess), $\mathrm{LiBr}$ (50 mg, catalytic), and [18]crown-6 (0.25 g, catalytic) in $\mathrm{MeCN}(200 \mathrm{~mL}$ ) was heated under reflux for $2 \mathrm{~d}$. After filtering off the inorganic salts, the filtrate was concentrated and purified by column chromatography ( $\mathrm{SiO}_{2}: \mathrm{CH}_{2} \mathrm{Cl}_{2} /$ hexanes, 9:1) to afford the naphthalene derivative $\mathbf{8}(1.85 \mathrm{~g}, 79 \%)$ as a pale yellow oil. ${ }^{1} \mathrm{H}$ NMR (500 MHz, $\left.\mathrm{CDCl}_{3}\right): \delta=1.21(\mathrm{~d}, J=7 \mathrm{~Hz}, 12 \mathrm{H}), 3.38-3.44(\mathrm{~m}, 2 \mathrm{H})$, 3.87-4.00 (m, 4H), 4.11 (t, $J=5 \mathrm{~Hz}, 2 \mathrm{H}), 4.37$ (t, $J=5 \mathrm{~Hz}, 2 \mathrm{H}), 5.24$ (s, 2H), 6.89-6.93 (dd, $J=8,12 \mathrm{~Hz}, 2 \mathrm{H}), 7.10(\mathrm{~d}, J=8 \mathrm{~Hz}, 3 \mathrm{H}), 7.34-7.43(\mathrm{~m}, 5 \mathrm{H}), 7.53(\mathrm{~d}, J=8 \mathrm{~Hz}, 2 \mathrm{H})$, 7.90-7.95 ppm (dd, $J=8,15 \mathrm{~Hz}, 2 \mathrm{H})$.

9. $\mathrm{H}_{2}$ gas was bubbled through a mixture of $8(1.85 \mathrm{~g}, 3.7 \mathrm{mmol})$, and $10 \% \mathrm{Pd}-\mathrm{C}(500$ $\mathrm{mg}$, catalytic) in EtOAc $(200 \mathrm{~mL})$ for $4 \mathrm{~h}$. After removal of the heterogeneous catalyst, the crude product was purified by column chromatography $\left(\mathrm{SiO}_{2}: \mathrm{CH}_{2} \mathrm{Cl}_{2}\right)$ to furnish the naphthol derivative $9(1.2 \mathrm{~g}, 78 \%)$ as a pale yellow solid. ${ }^{1} \mathrm{H} \mathrm{NMR}\left(500 \mathrm{MHz}, \mathrm{CD}_{2} \mathrm{Cl}_{3}\right): \delta$ $=1.21(\mathrm{~d}, J=7 \mathrm{~Hz}, 12 \mathrm{H}), 3.38-3.42(\mathrm{~m}, 2 \mathrm{H}), 3.88-4.01(\mathrm{~m}, 4 \mathrm{H}), 4.10-4.13(\mathrm{~d}$ of d, $J=$ $10 \mathrm{~Hz}, 2 \mathrm{H}), 4.37$ (t, $J=5 \mathrm{~Hz}, 2 \mathrm{H}), 6.84-6.89(\mathrm{~m}, 2 \mathrm{H}), 7.10(\mathrm{~d}, J=8 \mathrm{~Hz}, 3 \mathrm{H}), 7.26-7.28$ (m, 1H), 7.36-7.40 (m, 1H), $7.75(\mathrm{~d}, J=8 \mathrm{~Hz}, 1 \mathrm{H}), 7.90 \mathrm{ppm}(\mathrm{d}, J=8 \mathrm{~Hz}, 1 \mathrm{H}) . \mathrm{MS}$ (FAB) $m / z(\%) 408.49(100)[M]^{+}$.

11. This compound was prepared using a modification of the literature procedure. ${ }^{\mathrm{S4}} \mathrm{A}$ mixture of the alcohol 9 (615 $\mathrm{mg}, 1.5 \mathrm{mmol})$, the tosylate $10(500 \mathrm{mg}, 0.9 \mathrm{mmol})$, anhydrous $\mathrm{K}_{2} \mathrm{CO}_{3}$ (1.5 g, excess), $\mathrm{LiBr}(50 \mathrm{mg}$, catalytic) and [18]crown-6 (0.25 g, catalytic) in $\mathrm{MeCN}(100 \mathrm{~mL}$ ) was heated under reflux for $20 \mathrm{~h}$. After cooling down the reaction mixture, the inorganic salts were filtered out. The resulting yellow residue was coated onto $\mathrm{Al}_{2} \mathrm{O}_{3}$ and purified by column chromatography $\left(\mathrm{SiO}_{2}\right.$ : $\mathrm{CH}_{2} \mathrm{Cl}_{2} /$ hexanes, 9:1 to 
$\left.\mathrm{CH}_{2} \mathrm{Cl}_{2} / \mathrm{EtOH}, 98: 2\right)$ to afford the alcohol $11(460 \mathrm{mg}, 60 \%)$ as a bright yellow solid. ${ }^{1} \mathrm{H}$ NMR (500 MHz, $\left.\mathrm{CDCl}_{3}\right): \delta=1.18(\mathrm{~d}, J=7 \mathrm{~Hz}, 12 \mathrm{H}), 3.37-3.44(\mathrm{sept}, J=5 \mathrm{~Hz}, 2 \mathrm{H}$ ), 3.54-3.68 (m, 12H), 3.77-3.78 (m, 2H), 3.94-3.98 (m, 6H), 4.07-4.09 (m, 2H), $4.26(\mathrm{t}, J$ $=5 \mathrm{~Hz}, 2 \mathrm{H}), 4.28-4.30(\mathrm{~m}, 4 \mathrm{H}), 4.34(\mathrm{t}, J=5 \mathrm{~Hz}, 2 \mathrm{H}), 6.20-6.24(\mathrm{~m}, 2 \mathrm{H}), 6.87-6.92$ (dd, $J=8,15 \mathrm{~Hz}, 2 \mathrm{H}$ ), 7.07-7.10 (quint, $J=4 \mathrm{~Hz}, 3 \mathrm{H}$ ), 7.36-7.39 (dd, $J=8,17 \mathrm{~Hz}, 2 \mathrm{H}$ ), 7.84-7.88 ppm (dd, $J=8,13 \mathrm{~Hz}, 2 \mathrm{H})$.

12. This compound was prepared by using a modification of the literature procedure. ${ }^{\mathrm{S4}} \mathrm{A}$ solution of $p$ - $\mathrm{TsCl}(160 \mathrm{mg}, 0.84 \mathrm{mmol})$ in $\mathrm{CH}_{2} \mathrm{Cl}_{2}(25 \mathrm{~mL})$ was added dropwise at $0{ }^{\circ} \mathrm{C}$ to a solution of the alcohol $11(460 \mathrm{mg}, 0.55 \mathrm{mmol}), \mathrm{Et}_{3} \mathrm{~N}(0.15 \mathrm{~mL}, 1.1 \mathrm{mmol})$ and 4dimethylaminopyridine (DMAP) in $\mathrm{CH}_{2} \mathrm{Cl}_{2}(50 \mathrm{~mL})$. After stirring the reaction mixture at room temperature for $15 \mathrm{~h}$, it was coated onto $\mathrm{Al}_{2} \mathrm{O}_{3}$ and concentrated. Column chromatography $\left(\mathrm{SiO}_{2}: \mathrm{CH}_{2} \mathrm{Cl}_{2}\right.$ to $\left.\mathrm{CH}_{2} \mathrm{Cl}_{2} / \mathrm{EtOH}, 99: 1\right)$ afforded the pure tosylate 12 (450 $\mathrm{mg}, 84 \%)$ as a yellow solid. ${ }^{1} \mathrm{H} \mathrm{NMR}\left(500 \mathrm{MHz}, \mathrm{CD}_{2} \mathrm{Cl}_{2}\right): \delta=1.18(\mathrm{~d}, J=7 \mathrm{~Hz}, 12 \mathrm{H})$, $2.44(\mathrm{~s}, 3 \mathrm{H}), 3.37-3.42(\mathrm{~m}, 2 \mathrm{H}), 3.53-3.55(\mathrm{~m}, 4 \mathrm{H}), 3.64-3.66(\mathrm{~m}, 4 \mathrm{H}), 3.76-3.78(\mathrm{~m}$, 2H), 3.95-3.98 (m, 6H), 4.08-4.13 (m, 4H), 4.23 (br s, 2H), 4.29 (br s, 4H), 4.35-4.36 (m, 2H), $6.21(\mathrm{~d}, J=5 \mathrm{~Hz}, 2 \mathrm{H}), 6.87-6.92(\mathrm{dd}, J=8,15 \mathrm{~Hz}, 2 \mathrm{H}), 7.98(\mathrm{~m}, 3 \mathrm{H}), 7.34-$ 7.39 (dd, $J=8,16 \mathrm{~Hz}, 4 \mathrm{H}), 7.77$ (d, $J=8 \mathrm{~Hz}, 2 \mathrm{H}), 7.84-7.89 \mathrm{ppm}(\mathrm{dd}, J=8,13 \mathrm{~Hz}, 2 \mathrm{H})$.

14. A mixture of the tosylate $12(505 \mathrm{mg}, 0.5 \mathrm{mmol})$, the phenol derivative $\mathrm{e}^{\mathrm{s5}} \mathbf{1 3}(210 \mathrm{mg}$, $1 \mathrm{mmol}$ ), anhydrous $\mathrm{K}_{2} \mathrm{CO}_{3}$ (1 g, excess), $\mathrm{LiBr}$ (50 mg, catalytic) and [18]crown-6 (0.25 $\mathrm{g}$, catalytic) in $\mathrm{MeCN}(70 \mathrm{~mL})$ was heated under reflux for $20 \mathrm{~h}$. After removing the inorganic solids, the crude product was coated onto $\mathrm{Al}_{2} \mathrm{O}_{3}$ and concentrated. Column chromatography ( $\mathrm{SiO}_{2}: \mathrm{CH}_{2} \mathrm{Cl}_{2}$ to $\mathrm{CH}_{2} \mathrm{Cl}_{2} / \mathrm{MeOH}, 98: 2$ ) afforded the dumbbell-shaped compound 14 (410 mg, 80\%) as a yellow solid. ${ }^{1} \mathrm{H}$ NMR (500 MHz, $\left.\mathrm{CD}_{2} \mathrm{Cl}_{2}\right): \delta=1.18$ (m, 24H), 3.36-3.43 (sept, $J=6 \mathrm{~Hz}, 4 \mathrm{H}), 3.63-3.68$ (m, 4H), 3.69-3.73 (m, 2H), 3.76$3.78(\mathrm{~m}, 2 \mathrm{H}), 3.79-3.82(\mathrm{~m}, 2 \mathrm{H}), 3.87-3.88(\mathrm{~m}, 2 \mathrm{H}), 3.94-3.98(\mathrm{~m}, 6 \mathrm{H}), 4.08(\mathrm{t}, J=8$ $\mathrm{Hz}, 2 \mathrm{H}), 4.29(\mathrm{t}, J=5 \mathrm{~Hz}, 6 \mathrm{H}), 4.34(\mathrm{t}, J=5 \mathrm{~Hz}, 2 \mathrm{H}), 4.58(\mathrm{~d}, J=4 \mathrm{~Hz}, 2 \mathrm{H}), 6.21-6.26$ (2 x br s, 2H), 6.87-6.93 (dd, $J=8,15 \mathrm{~Hz}, 2 \mathrm{H}), 7.05-7.10$ (m, 5H), 7.34-7.39 (dd, $J=8$, $16 \mathrm{~Hz}, 2 \mathrm{H}$ ), 7.84-7.89 ppm (dd, $J=8,13 \mathrm{~Hz}, 2 \mathrm{H}$ ). MS (HR-MALDI) $\mathrm{m} / z 1020.4063$ $[M]^{+}$(DHB matrix). 


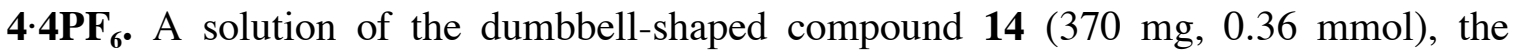
bis(hexafluorophosphate) $\quad$ salt $^{\mathrm{s} 6} \quad \mathbf{1 5}^{2} \cdot \mathrm{PF}_{6} \quad\left(\begin{array}{llll}766 & \mathrm{mg}, & 1.08 & \mathrm{mmol}\end{array}\right)$, and $\quad 1,4-$ bis(bromomethyl)benzene (287 mg, $1.08 \mathrm{mmol})$ in DMF (37 mL) was stirred at room temperature for $10 \mathrm{~d}$. The reaction mixture was then poured into $\mathrm{Et}_{2} \mathrm{O}(400 \mathrm{~mL})$ and the resulting greenish precipitate was collected. The residue was dissolved in a minimum volume of $\mathrm{Me}_{2} \mathrm{CO}$ and subjected to column chromatography $\left(\mathrm{SiO}_{2}\right)$. The unreacted 14 was recovered by eluting the column with $\mathrm{Me}_{2} \mathrm{CO}$, whereupon the eluent was changed to $\mathrm{Me}_{2} \mathrm{CO} / \mathrm{NH}_{4} \mathrm{PF}_{6}\left(1 \mathrm{~g} \mathrm{NH}_{4} \mathrm{PF}_{6}\right.$ in $\left.100 \mathrm{~mL} \mathrm{Me} 2 \mathrm{CO}\right)$ and the green band containing the [2]rotaxane $4 \cdot 4 \mathrm{PF}_{6}$ was collected. After the removal of solvent, $\mathrm{H}_{2} \mathrm{O}(150 \mathrm{ml})$ was added to the residue and the resulting precipitate was recovered by filtration to obtain the pure rotaxane $4 \cdot 4 \mathrm{PF}_{6}(292 \mathrm{mg}, 42 \%)$ as a green solid. ${ }^{1} \mathrm{H}$ NMR $\left(500 \mathrm{MHz}, \mathrm{CD}_{3} \mathrm{CN}\right): \delta=1.13$ (d, $J=7 \mathrm{~Hz}, 24 \mathrm{H}), 3.32-3.41(\mathrm{~m}, 4 \mathrm{H}), 3.83-3.88(\mathrm{~m}, 4 \mathrm{H}), 3.91(\mathrm{~d}, J=5 \mathrm{~Hz}, 4 \mathrm{H}), 3.96-$ $4.02(\mathrm{~m}, 8 \mathrm{H}), 4.09-4.15(\mathrm{~m}, 6 \mathrm{H}), 4.22-4.36(\mathrm{~m}, 6 \mathrm{H}), 4.64$ (br s, 2H), 5.43-5.54 (m, 4H), 5.62-5.70 (m, 4H), 5.97, 6.01, 6.14 and $6.19(4 \mathrm{x} \mathrm{s}, 2 \mathrm{H}), 6.77-6.84(\mathrm{~m}, 2 \mathrm{H}), 7.03-7.11$ (m, 5H), 7.20-7.27 (m, 2H), 7.37-7.43 (dd, $J=8,18 \mathrm{~Hz}, 2 \mathrm{H}), 7.56-7.70(\mathrm{~m}, 16 \mathrm{H})$, 8.65-9.20 ppm (m, 8H). MS (HR-ESI) $m / z 1976.6462\left[M-\mathrm{PF}_{6}\right]^{+}, 915.7985\left[M-2 \mathrm{PF}_{6}\right]^{2+}$, $562.2045\left[M-3 \mathrm{PF}_{6}\right]^{3+}$.

1.4PF . 4-Methylmorpholine ( $0.5 \mathrm{~mL}$, excess) was added to a solution of the $\mathrm{P}-\mathrm{C}_{60}$ dyad ${ }^{\mathrm{S1}} \mathbf{3}(200 \mathrm{mg}, 0.11 \mathrm{mmol})$ in $\mathrm{THF} / \mathrm{CH}_{2} \mathrm{Cl}_{2}(70 \mathrm{~mL}, 5: 2)$ and the resulting reaction mixture was stirred at room temperature for $10 \mathrm{~min}$. Subsequently, 2-chloro-4,6dimethoxy-1,3,5-triazine $(25 \mathrm{mg}, 0.14 \mathrm{mmol})$ was added to the reaction mixture at $0^{\circ} \mathrm{C}$. The resulting solution was stirred at $0^{\circ} \mathrm{C}$ for $10 \mathrm{~min}$ and then at room temperature for $3 \mathrm{~h}$. A thin layer chromatogram (TLC) of this solution showed the appearance of a less polar component (activated ester) at the expense of the starting material 3. Subsequently, a solution of the rotaxane $4 \cdot 4 \mathrm{PF}_{6}(170 \mathrm{mg}, 0.08 \mathrm{mmol})$ and 4-dimethylaminopyridine (70 $\mathrm{mg}$ ) in THF $(50 \mathrm{~mL})$ was added to the reaction mixture and it was stirred at room temperature for $5 \mathrm{~h}$. A TLC of the reaction mixture showed the disappearance of the activated ester and the appearance of a very polar compound. After removing the solvents at room temperature, the residue was thoroughly washed with $\mathrm{Et}_{2} \mathrm{O}(100 \mathrm{~mL}), \mathrm{CH}_{2} \mathrm{Cl}_{2}$ (200 mL), $\mathrm{MeOH}(200 \mathrm{~mL})$, and again with $\mathrm{CH}_{2} \mathrm{Cl}_{2}(100 \mathrm{~mL})$ in order to remove all the 
reagents and starting materials to afford the multicomponent [2] rotaxane $1 \cdot 4 \mathrm{PF}_{6}(285 \mathrm{mg}$, $90 \%)$ as a purple solid. ${ }^{1} \mathrm{H}$ NMR $\left(500 \mathrm{MHz},\left(\mathrm{CD}_{3}\right)_{2} \mathrm{NCDO}\right): \delta=-2.76$ (br s, $\left.2 \mathrm{H}\right), 1.12-$ $1.16(\mathrm{~m}, 12 \mathrm{H}), 1.25-1.27(\mathrm{~m}, 12 \mathrm{H}), 1.56(\mathrm{~s}, 36 \mathrm{H}), 3.38-3.50(\mathrm{~m}, 4 \mathrm{H}), 3.80-4.53(\mathrm{~m}$, 24H), 4.83 (s, 1H), $5.26(\mathrm{~s}, 1 \mathrm{H}), 5.57(\mathrm{~s}, 1 \mathrm{H}), 5.62(\mathrm{~s}, 1 \mathrm{H}), 5.80(\mathrm{~s}, 2 \mathrm{H}), 6.00-6.30(\mathrm{~m}$, 8H), $6.48(\mathrm{~m}, 2 \mathrm{H}), 6.85(\mathrm{~d}, 2 \mathrm{H}), 7.08-7.20$ (m, 4H), 7.39-7.41 (m, 2H), 7.49-7.55 (m, 4H), 7.74-7.89 (m, 6H), 8.01-8.26 (m, 14H), 8.36-8.58 (m, 10H), 8.86-9.03 (m, 8H), 9.60-9.83 ppm (m, 8H). MS (HR-ESI) $m / z 1825.5467\left[M-2 \mathrm{PF}_{6}\right]^{2+}, 1168.6971[M-$ $\left.3 \mathrm{PF}_{6}\right]^{3+}, 840.2734\left[M-4 \mathrm{PF}_{6}\right]^{4+}$.

2. 4-Methylmorpholine $(0.5 \mathrm{~mL}$, excess $)$ was added to a solution of the $\mathrm{P}-\mathrm{C}_{60}$ dyad ${ }^{\mathrm{S}} \mathbf{3}$ (200 $\mathrm{mg}, 0.11 \mathrm{mmol})$ in $\mathrm{THF} / \mathrm{CH}_{2} \mathrm{Cl}_{2}(100 \mathrm{~mL}, 4: 1)$ and the resulting reaction mixture was stirred at room temperature for $10 \mathrm{~min}$. Subsequently, 2-chloro-4,6-dimethoxy-1,3,5triazine $(24 \mathrm{mg}, 0.14 \mathrm{mmol})$ was added to the reaction mixture at $0^{\circ} \mathrm{C}$. The resulting solution was stirred at $0^{\circ} \mathrm{C}$ for $10 \mathrm{~min}$ and then at room temperature for $3 \mathrm{~h}$. A TLC showed the appearance of a less polar component corresponding to the activated ester at the expense of the starting material 3. Subsequently, a solution of the alcohol $11(270 \mathrm{mg}$, $0.33 \mathrm{mmol})$ and 4-dimethylaminopyridine $(100 \mathrm{mg})$ in $\mathrm{THF}(30 \mathrm{~mL})$ was added to the reaction mixture and it was stirred at room temperature for $5 \mathrm{~h}$. After removing the solvents, $\mathrm{MeOH}(50 \mathrm{~mL})$ was added to the residue, and the resulting precipitate was collected by filtration, followed by thorough washing of the precipitate with $\mathrm{MeOH}$. The residue was dissolved in $\mathrm{CH}_{2} \mathrm{Cl}_{2}(50 \mathrm{~mL})$ and the resulting purple solution was filtered. Finally, removal of solvents from the filtrate afforded the tetrad $2(250 \mathrm{mg}, 95 \%)$ as a purple solid. ${ }^{1} \mathrm{H}$ NMR $\left(500 \mathrm{MHz}, \mathrm{CDCl}_{3}\right): \delta=-2.81$ (s, 2H), 1.18-1.25 (m, 12H), 1.491.60 (br s, 36H), 3.35-3.44 (sept, $J=5 \mathrm{~Hz}, 2 \mathrm{H}), 3.61-3.83$ (m, 12H), 3.95-4.00 (m, 6H), $4.10(\mathrm{t}, J=5 \mathrm{~Hz}, 4 \mathrm{H}) 4.25-4.36(\mathrm{~m}, 4 \mathrm{H}), 4.68(\mathrm{br} \mathrm{s}, 2 \mathrm{H}), 4.81(\mathrm{~d}, J=10 \mathrm{~Hz}, 1 \mathrm{H}), 5.49$ (d, $J=10 \mathrm{~Hz}, 1 \mathrm{H}), 5.90(\mathrm{~s}, 1 \mathrm{H}), 6.16,6.19,6.21$ and $6.23(4 \mathrm{x} \mathrm{s}, 2 \mathrm{H}), 6.85-6.89(\mathrm{~m}, 2 \mathrm{H})$, $7.08(\mathrm{~d}, J=8 \mathrm{~Hz}, 8 \mathrm{H}), 7.29-7.38(\mathrm{~m}, 4 \mathrm{H}), 7.76-7.90(\mathrm{~m}, 8 \mathrm{H}), 8.07$ (s, 4H), 8.26-8.32 $(\mathrm{m}, 4 \mathrm{H}), 8.45-8.49(\mathrm{~m}, 2 \mathrm{H}), 8.77-8.80(\mathrm{~m}, 4 \mathrm{H}), 8.89-8.91 \mathrm{ppm}(\mathrm{m}, 4 \mathrm{H})$. MS (HRMALDI) $m / z, 2650.4862[M+\mathrm{H}]^{+}$(anthracene matrix). 
UV-Vis-NIR Spectroscopy and Electrochemical Studies. All the experiments were performed at room temperature (ca. $298 \mathrm{~K}$ ). The solvents (MeCN, THF and DMF) and chemicals $\left(\mathrm{NBu}_{4} \mathrm{PF}_{6}, \mathrm{Fe}\left(\mathrm{ClO}_{4}\right)_{3} \cdot x \mathrm{H}_{2} \mathrm{O}\right.$ and $\mathrm{NOBF}_{4}$, purchased from Aldrich or Fluka) were used as received.

The UV-Vis-NIR absorption spectra were recorded on a Perkin Elmer $\lambda 40$ spectrophotometer in air equilibrated MeCN, THF or DMF (Merck Uvasol) solutions with concentrations ranging from $1.0 \times 10^{-6}$ to $5.0 \times 10^{-4} \mathrm{M}$.

The electrochemical and spectroelectrochemical experiments were carried out in argon-purged THF or DMF (Romil Hi-Dry) solutions at concentrations ranging from $1.0 \times 10^{-4}$ to $1.0 \times 10^{-3} \mathrm{M}$ and with $0.1 \mathrm{M}$ tetrabutylammonium hexafluorophosphate $\left(\mathrm{TBAPF}_{6}\right)$ as supporting electrolyte. The useful electrochemical window in these conditions was from -1.9 to $+1.4 \mathrm{~V}$ vs SCE in THF and from -1.9 to $+1.5 \mathrm{~V}$ vs SCE in DMF. Cyclic voltammetric (CV) and differential pulse voltammetric (DPV) experiments were performed with an Autolab 30 multipurpose instrument interfaced to a PC using a glassy carbon working electrode $\left(0.08 \mathrm{~cm}^{2}\right.$, Amel), a Pt spiral - separated from the bulk solution with a fine glass frit- as the counter electrode, and a silver wire as a pseudoreference electrode. The surface of the working electrode was polished routinely with a $0.05 \mu \mathrm{m}$ alumina-water slurry on a felt surface immediately before use. In some instances a Pt working electrode was also employed, but its response was not better than that of glassy carbon. In all cases decamethylferrocene $\left(E_{1 / 2}=+0.157 \mathrm{~V}\right.$ in THF, $+0.041 \mathrm{~V}$ in $\mathrm{DMF}$, vs $\mathrm{SCE})^{\mathrm{S7}}$ was present as internal standard for the potential values. Cyclic voltammograms were obtained with sweep rates in the range $20-1000 \mathrm{mV} \mathrm{s}^{-1}$; the $i R$ compensation implemented within the Autolab 30 was used, and every effort was made throughout the experiments in order to minimize the resistance of the solution. In any instance, the full reversibility of the voltammetric wave of the internal standard was taken as an indicator of the absence of uncompensated resistance effects. The reversibility of the observed processes was established by using the criteria of (i) separation of $60 \mathrm{mV}$ between cathodic and anodic peaks, (ii) the close to unity ratio of the intensities of the cathodic and anodic currents, and (iii) the constancy of the peak potential on changing sweep rate in the cyclic voltammograms. The DPV experiments were performed with a 
scan rate of 20 or $4 \mathrm{mV} \mathrm{s}^{-1}$ (pulse height 75 and $10 \mathrm{mV}$, respectively) and a duration of 40 ms. For reversible processes, the same half-wave potential values were obtained from the DPV peaks and from an average of the cathodic and anodic CV peaks. The potential for irreversible processes was obtained from the DPV peak.

Spectroelectrochemical experiments were made in custom built optically-transparent thin layer electrochemical (OTTLE) cells. In a first setup, a OTTLE cell with an optical path of $1 \mathrm{~mm}$, equipped with a Pt grid as working electrode, a Pt wire as counter electrode and a Ag wire pseudo-reference electrode, was employed. The electrolysis was controlled by means of a Princeton Applied Research 263A Multipurpose instrument interfaced to a PC, and the absorption spectra were recorded on a Varian 100-Bio UV-Vis spectrophotometer. In order to achieve faster electrolyses, a second setup was also used, based on a different OTTLE cell ${ }^{58}$ having Pt minigrids (ca. $0.3 \mathrm{~cm}^{2}$ ) as the working and counter electrodes, and an Ag wire as a pseudo-reference electrode - all melt-sealed into a polyethylene spacer. The thickness of the layer, determined by spectrophotometry, was $180 \mu \mathrm{m}$. The electrolysis was controlled by means of the above described Autolab 30 instrument, and the absorption spectra were recorded on a Agilent Technologies 8543 diode array spectrophotometer. The electrolysis times were determined on the basis of the spectral changes observed, i.e., the electrolysis was stopped when no further spectral variations occurred.

The experimental errors are estimated to be as follows: absorption maxima, $\pm 2 \mathrm{~nm}$; absorption coefficients, $\pm 10 \%$; potential values, $\pm 10 \mathrm{mV}$ (reversible processes) or \pm 20 $\mathrm{mV}$ (irreversible processes).

Absorption spectra. The UV-Vis absorption spectra in THF solution of some model compounds for the multicomponent rotaxane $\mathbf{1}^{4+}$ are shown in Figures S1 and S2. The absorption spectrum of dyad $\mathbf{3}$ (Figure S1) is slightly different from the sum of the spectra of model compounds for its porphyrin (20) and fullerene (21) units. A decrease in intensity of the porphyrin peaks and an increase of absorption at around $300 \mathrm{~nm}$ indicates the occurrence of electronic interactions between the $\mathrm{C}_{60}$ and $\mathrm{P}$ units in the ground state. 


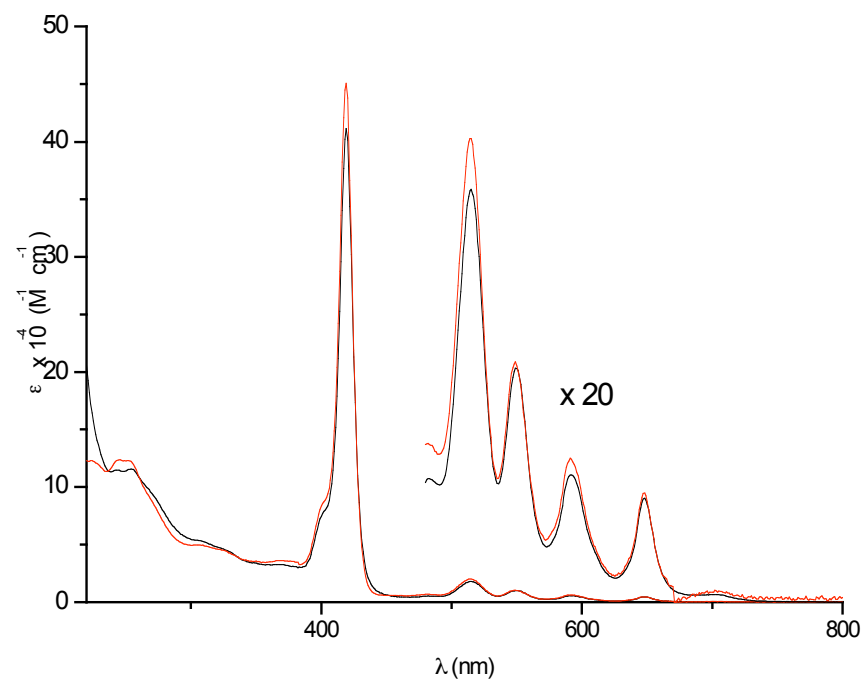

Figure S1. Absorption spectra (THF) of dyad 3 (black trace) and sum of the spectra of model compounds 20 and 21 (red trace).

As described in the main text, the absorption bands of triad 16 (Figure 4) are noticeably perturbed compared to those of its constituents. The absorption spectrum of tetrad 2 is very similar to that of parent triad $\mathbf{1 6}$ at wavelengths longer than $350 \mathrm{~nm}$ (Figure S2), suggesting the fact that the sharp absorption features of the DNP unit at $\lambda<$ $350 \mathrm{~nm}$ are no longer observed in $\mathbf{2}$ indicates that such a unit is also engaged in CT interactions with the other chromophoric components.

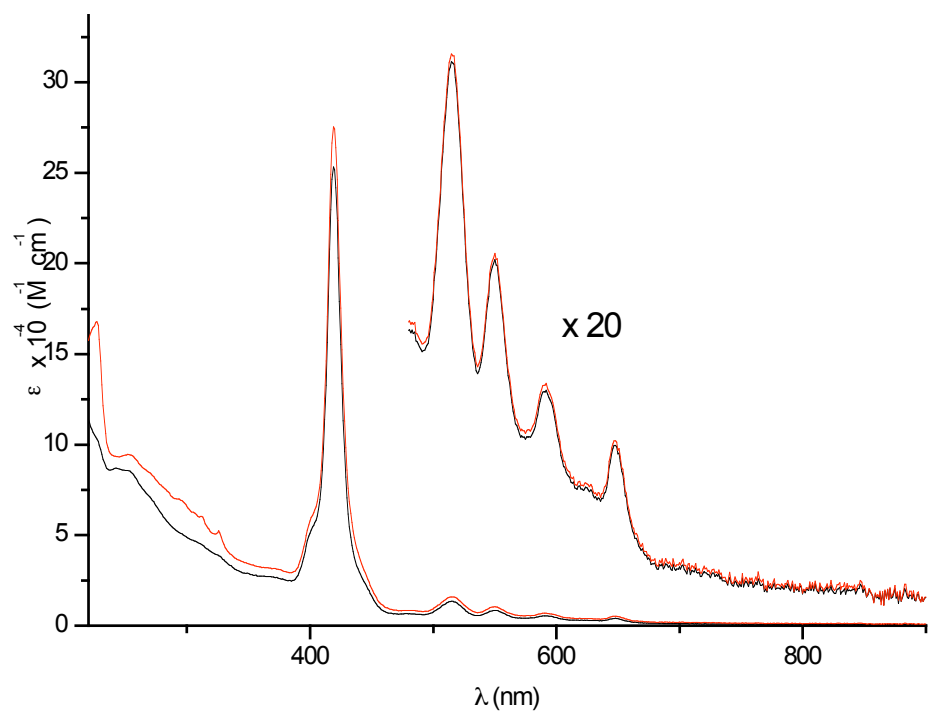

Figure S2. Absorption spectra (THF) of tetrad 2 (black trace) and sum of the spectra of triad $\mathbf{1 6}$ and DNP model 18 (red trace). The absorption spectrum of $\mathbf{2}$ in DMF is nearly identical to that in THF. 
Figure $\mathrm{S} 3$ shows a comparison of the charge-transfer absorption bands of $\mathbf{1}^{4+}$ and model rotaxane $4^{4+}$. Since the electrochemical data indicate that in $\mathbf{4}^{4+}$ the $\mathrm{CBPQT}^{4+}$ ring is located exclusively on the TTF station (vide infra), on the basis of the molar absorption coefficient of the band observed for $4^{4+}$ one can estimate that the $\mathrm{CBPQT}^{4+}$ ring is engaged in CT interactions with the TTF station in about $75 \%$ of the $\mathbf{1}^{4+}$ species. This behavior could be caused by a competition between $\mathrm{CBPQT}^{4+}$ and $\mathrm{C}_{60}$ electron acceptors for the electron donating TTF unit. In such a case, it may be expected that in $25 \%$ of the $\mathbf{1}^{4+}$ species the $\mathrm{CBPQT}^{4+}$ surrounds the DNP station; however, this hypothesis cannot be confirmed because the weak DNP-CBPQT ${ }^{4+} \mathrm{CT}$ band $\left(\lambda_{\max }=515 \mathrm{~nm}, \varepsilon=650 \mathrm{M}^{-1} \mathrm{~cm}^{-1}\right.$ in $\mathrm{MeCN}$ ) would be buried under the intense bands of the porphyrin chromophore, and therefore undetectable.

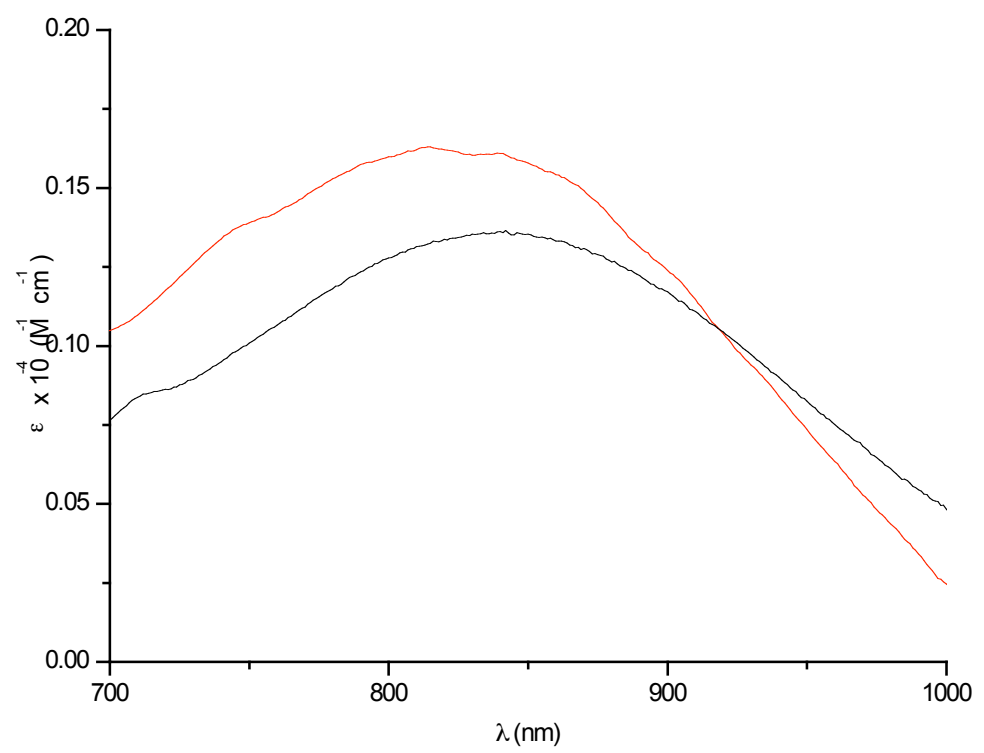

Figure S3. Detail of the TTF/CBPQT ${ }^{4+}$ CT absorption bands (DMF) of rotaxanes $\mathbf{1}^{4+}$ (black trace) and $\mathbf{4}^{4+}$ (red trace). Because the dumbbell-shaped tetrad 2 shows an absorption tail in the 700$1000 \mathrm{~nm}$ region, the CT band for $\mathbf{1}^{4+}$ is obtained by subtracting the absorption spectrum of $\mathbf{2}$ from that of $\mathbf{1}^{4+}$.

Electrochemistry. Figure S4 shows the cyclic voltammetric curve for triad $\mathbf{1 6}$ in THF and in a THF/MeCN 85:15 mixture. It can be noticed that in THF the oxidation processes of the TTF unit exhibit electrochemical irreversibility as well as a current intensity ca. $30 \%$ weaker than that of the monoelectronic reduction of the fullerene unit observed at $-0.51 \mathrm{~V}$. 
The lack of electrochemical reversibility and the decrease in the current intensity for TTF oxidation could be explained by the presence of folded conformations in which such unit is shielded and cannot approach the electrode surface. This hypothesis is consistent with the fact that the electrochemical reversibility and current intensity of the TTF oxidation processes increase by adding $15 \%$ of $\mathrm{MeCN}$ to the THF solution (Figure S4) in order to improve solvation.

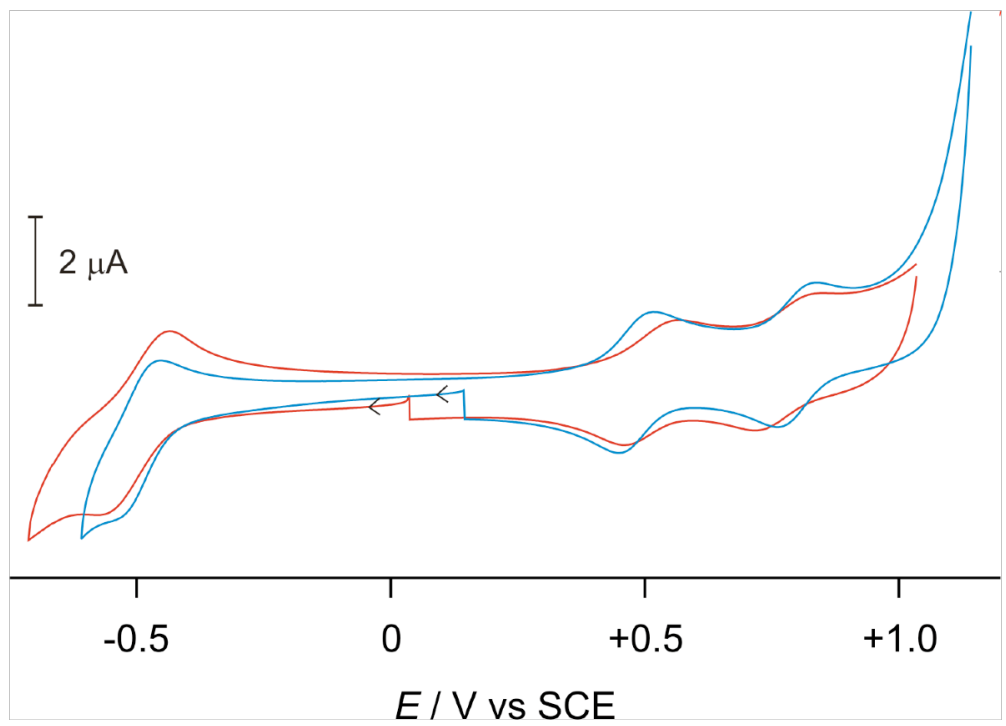

Figure S4. Cyclic voltammograms of triad $\mathbf{1 6}$ in THF (red trace) and in THF/MeCN 85:15 (blue trace). Conditions: $3.0 \times 10^{-4} \mathrm{M}$, glassy carbon electrode, $\mathrm{TBAPF}_{6} 0.1 \mathrm{M}, 100 \mathrm{mV} / \mathrm{s}$.

The voltammetric behavior for tetrad $\mathbf{2}$ is similar to that of triad $\mathbf{1 6}$ as far as the TTF oxidation is concerned. As shown in Figure S5, the current intensities associated with these processes are again considerably weaker than that for the monoelectronic reduction of the fullerene moiety $(-0.48 \mathrm{~V})$, suggesting the presence of folded conformations (Figure 5) which in this case are not affected by the addition of up to $20 \%$ $\mathrm{MeCN}$ to the THF solution. 


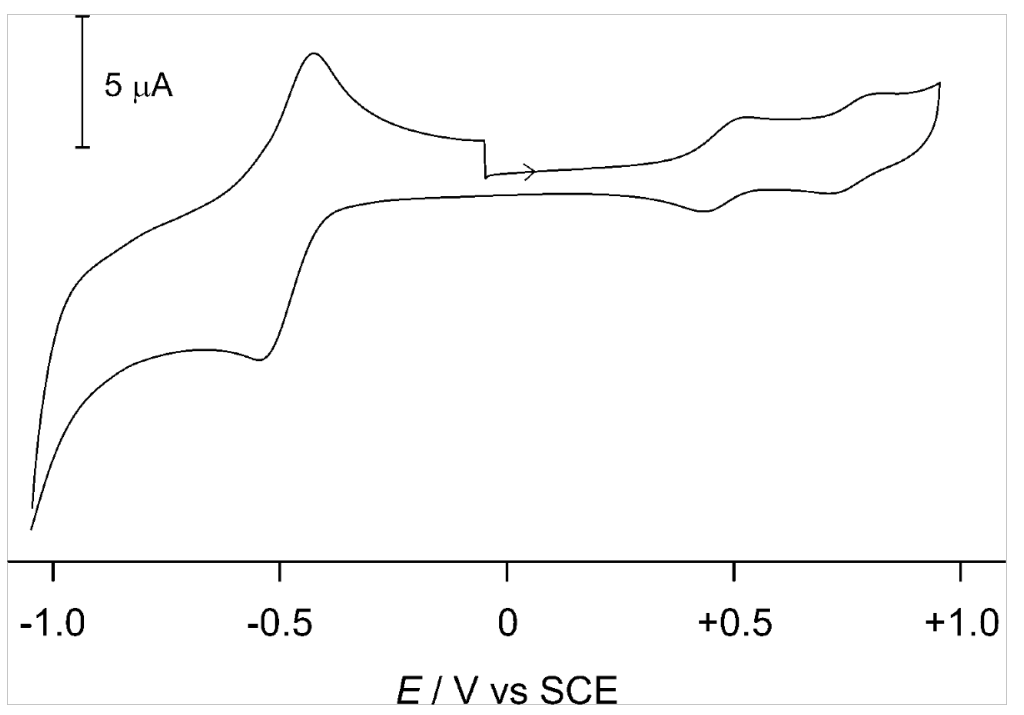

Figure S5. Cyclic voltammograms of tetrad 2 in THF. Note the difference in current intensity between the first reduction of the fullerene moiety $(-0.48 \mathrm{~V})$ and the two TTF oxidation processes $(+0.48$ and $+0.77 \mathrm{~V})$. All these processes should involve the exchange of one electron. Conditions: $5.0 \times 10^{-4} \mathrm{M}$, glassy carbon electrode, $\mathrm{TBAPF}_{6} 0.1 \mathrm{M}, 200 \mathrm{mV} / \mathrm{s}$.

Figure S6 shows a comparison of the cyclic voltammogram of rotaxane $4^{4+}$ with those of its molecular components, $\mathrm{CBPQT}^{4+}$ and dumbbell 17. In rotaxane $4^{4+}$ the first two reduction processes $(-0.29$ and $-0.36 \mathrm{~V}$ vs SCE, Table 1$)$ are assigned to the reversible one-electron reduction of each of the two bipyridinium units present in the $\mathrm{CBPQT}^{4+}$ ring. These potential values are more negative than the corresponding first (two-electron) process measured for $\mathrm{CBPQT}^{4+}$ alone because of the $\mathrm{CT}$ interaction with the TTF unit. The small albeit detectable splitting of the $\mathrm{CBPQT}^{4+2+}$ reduction into two monoelectronic waves shows that in $4^{4+}$ the two bipyridinium units of the ring, which are expected to be topologically equivalent, are not electrochemically equivalent. Such an effect is attributed to the fact that the $\mathrm{CBPQT}^{4+}$ ring, while encircling a given electron donating station, is involved in alongside interactions with the other electron-rich units. Such a behavior implies the presence of folded conformations wherein the two bipyridinium sides of the ring experience chemically different environments. The bielectronic process observed at $-0.73 \mathrm{~V}$ is assigned to the reduction of $\mathrm{CBPQT}^{2+}$ to its neutral form $\left(\mathrm{CBPQT}^{0}\right)$. The fact that also this process is negatively shifted compared to the same process in the free cyclophane indicates that $\mathrm{CBPQT}^{2+}$ is still involved in electronic interactions with the dumbbell-shaped component. The bielectronic nature of 
the process indicates that, in the doubly reduced $4^{2+}$ rotaxane, the two bipyridinium units of the ring gain topological equivalence.

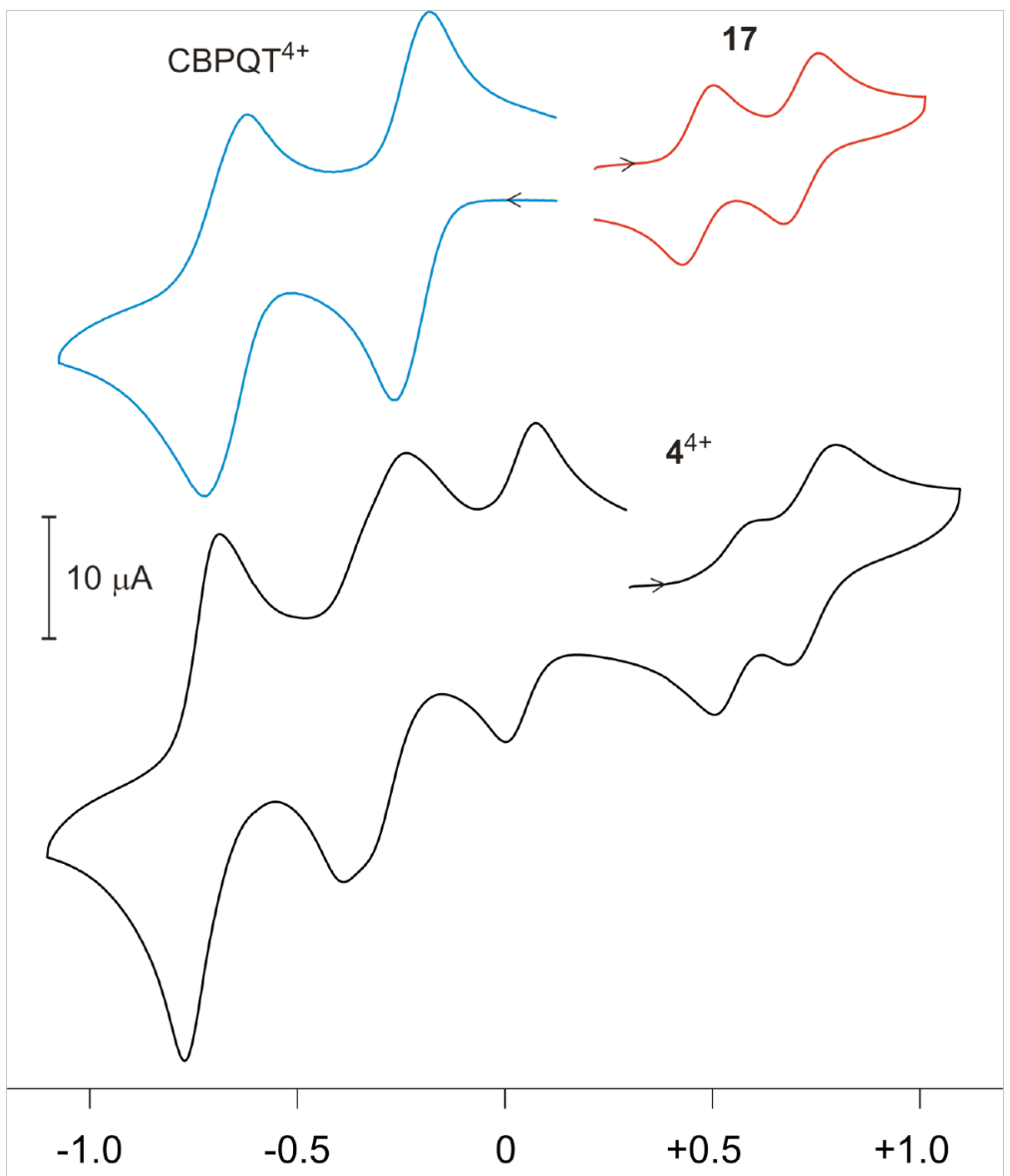

E I V vs SCE

Figure S6. Cyclic voltammograms of model rotaxane $4^{4+}$ (black trace) and its molecular components, $\mathrm{CBPQT}^{4+}$ (blue trace) and dumbbell-shaped compound 17 (red trace) in DMF. The wave with $E_{1 / 2}=+0.041 \mathrm{~V}$ is that of decamethylferrocene used as a reference standard. Conditions: $8.0 \times 10^{-4} \mathrm{M}$, glassy carbon electrode, TBAPF $6.1 \mathrm{M}, 200 \mathrm{mV} / \mathrm{s}$. The $\mathrm{CV}$ curves for the molecular components have been corrected ${ }^{\mathrm{S9}}$ to take into account differences in the diffusion coefficient with respect to that of the rotaxane.

The two redox waves on the positive potentials region are assigned to oxidation of the TTF unit. The first oxidation process is anodically shifted $(+90 \mathrm{mV})$ compared to the same process in $\mathbf{1 7}$, whereas the second TTF oxidation occurs at a very similar potential. This behavior indicates that (i) the $\mathrm{CBPQT}^{4+}$ ring is initially located onto the TTF station (no oxidation process at $+0.46 \mathrm{~V}$, where oxidation of the uncomplexed TTF unit would be expected to occur, is observed), and (ii) after the first oxidation of this unit the ring 
moves away, leaving the second oxidation process unaltered compared to that in the dumbbell-shaped component.

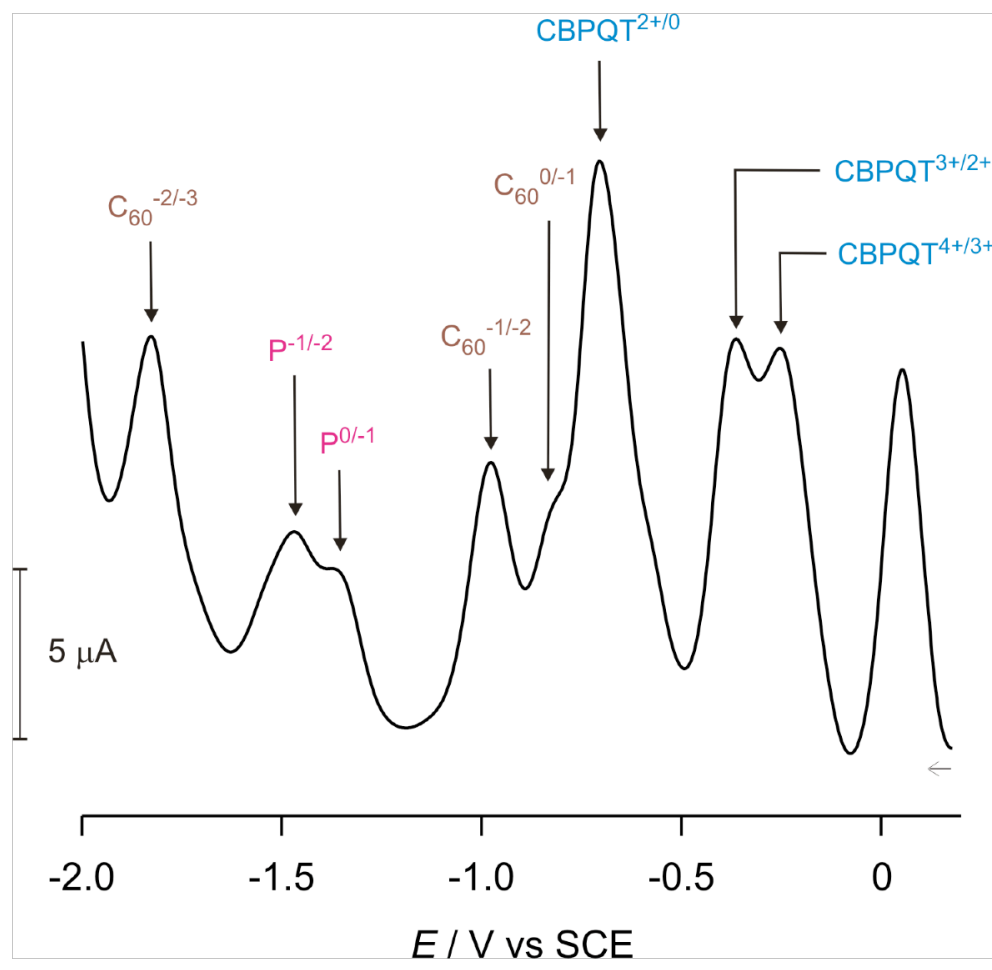

Figure S7. Differential pulse voltammogram in the region of negative potentials of rotaxane $\mathbf{1}^{4+}$ in DMF. The peak at $+0.041 \mathrm{~V}$ is that of decamethylferrocene used as a reference standard. Each peak is assigned to the corresponding redox-active site. Conditions: $5.2 \times 10^{-4} \mathrm{M}$, glassy carbon electrode, TBAPF $_{6} 0.1 \mathrm{M}, 20 \mathrm{mV} / \mathrm{s}$, pulse height $10 \mathrm{mV}$.

Figure S7 shows the differential pulse voltammetric (DPV) curve of rotaxane $\mathbf{1}^{4+}$ in the region of negative potentials. From a comparison with Figure 6 it can be noticed that DPV offers a much higher sensitivity than CV, particularly as far as irreversible processes are concerned. Many reduction processes can be observed, each assigned to the corresponding electroactive site by comparison with model compounds. The first two monoelectronic processes $(-0.28$ and $-0.39 \mathrm{~V}$, Table 1$)$ are safely assigned to the $\mathrm{CBPQT}^{4+/ 2+}$ reduction. The bielectronic nature of the third process $(-0.73 \mathrm{~V})$ allows its attribution to the $\mathrm{CBPQT}^{4+/ 2+}$ reduction. We assign the successive process $(-0.84 \mathrm{~V})$ to the first reduction of the $\mathrm{C}_{60}$ unit. It can be noticed that this process occurs at a considerably more negative potential than that $(-0.45 \mathrm{~V})$ of fulleropyrrolidine in DMF. ${ }^{\mathrm{S} 10}$ The reason for such a large cathodic shift is not clear; however, it should be considered 
that in $\mathbf{1}^{4+}$ the reduction of the fullerene unit has to take place when four electrons have already been uptaken by the molecule.

Spectroelectrochemistry. Figure S8 shows the absorption spectral changes observed upon oxidation of the TTF model 19 in DMF. Application of a potential of $+0.65 \mathrm{~V}$ causes the appearance of absorption bands at 450 and $600 \mathrm{~nm}$ typical of the $\mathrm{TTF}^{+}$form. These bands increase up to complete mono-oxidation of the TTF units (Figure S8, green trace). Subsequent exhaustive electrolysis at $-0.2 \mathrm{~V}$ regenerates the original spectrum (black trace), indicating that in these conditions the oxidation to $\mathrm{TTF}^{+}$is reversible. Exhaustive electrolysis at $+1.1 \mathrm{~V}$ causes spectral changes consistent with the formation of the $\mathrm{TTF}^{2+}$ species. However, upon back electrolysis at $-0.2 \mathrm{~V}$ the original TTF spectrum is not regenerated (red trace). This observation indicates that the oxidation to $\mathrm{TTF}^{2+}$ is not reversible, presumably because the dication is involved in a irreversible redox reaction with DMF.

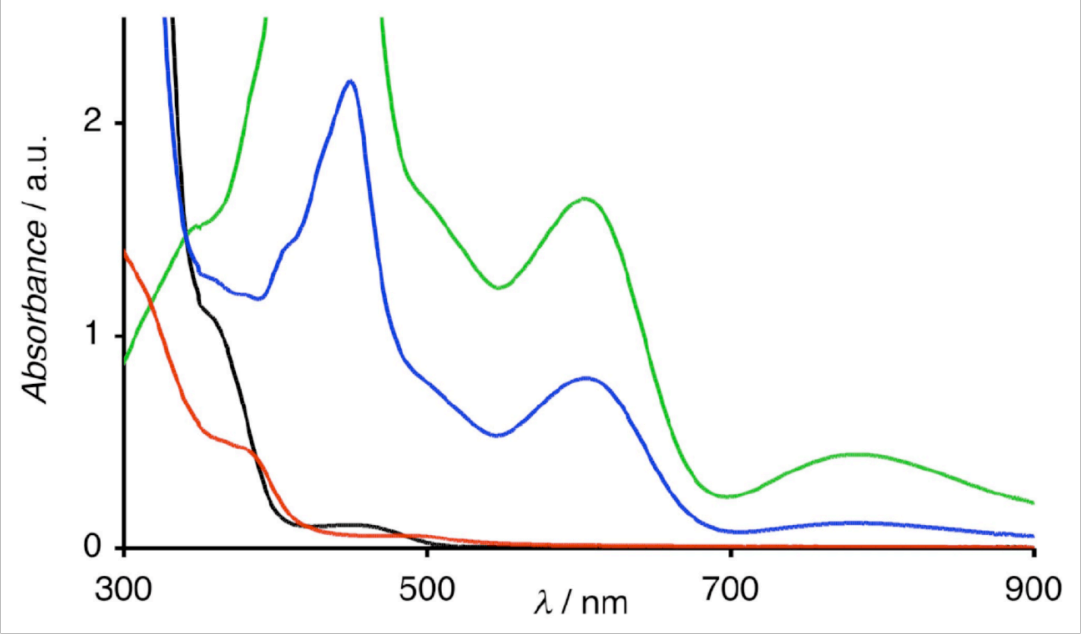

Figure S8. Absorption spectral changes observed upon electrochemical oxidation of TTF model 19 in DMF. Conditions: $4.0 \times 10^{-3} \mathrm{M}, \mathrm{TBAPF}_{6} 0.1 \mathrm{M}$, optical path length $1 \mathrm{~mm}$. Black trace: initial spectrum. Blue trace: after electrolysis at $+0.65 \mathrm{~V}$ (vs $\mathrm{Ag}$ pseudo-reference electrode) corresponding to ca. $50 \%$ oxidation to the $\mathrm{TTF}^{+}$state. Green trace: complete conversion to $\mathrm{TTF}^{+}$. Subsequent exhaustive electrolysis at $-0.2 \mathrm{~V}$ regenerates the original spectrum (black trace). The spectrum corresponding to the red trace was obtained after oxidation to the $\mathrm{TTF}^{2+}$ state (electrolysis at $+1.1 \mathrm{~V}$ ) and subsequent electrolysis at $-0.2 \mathrm{~V}$. 


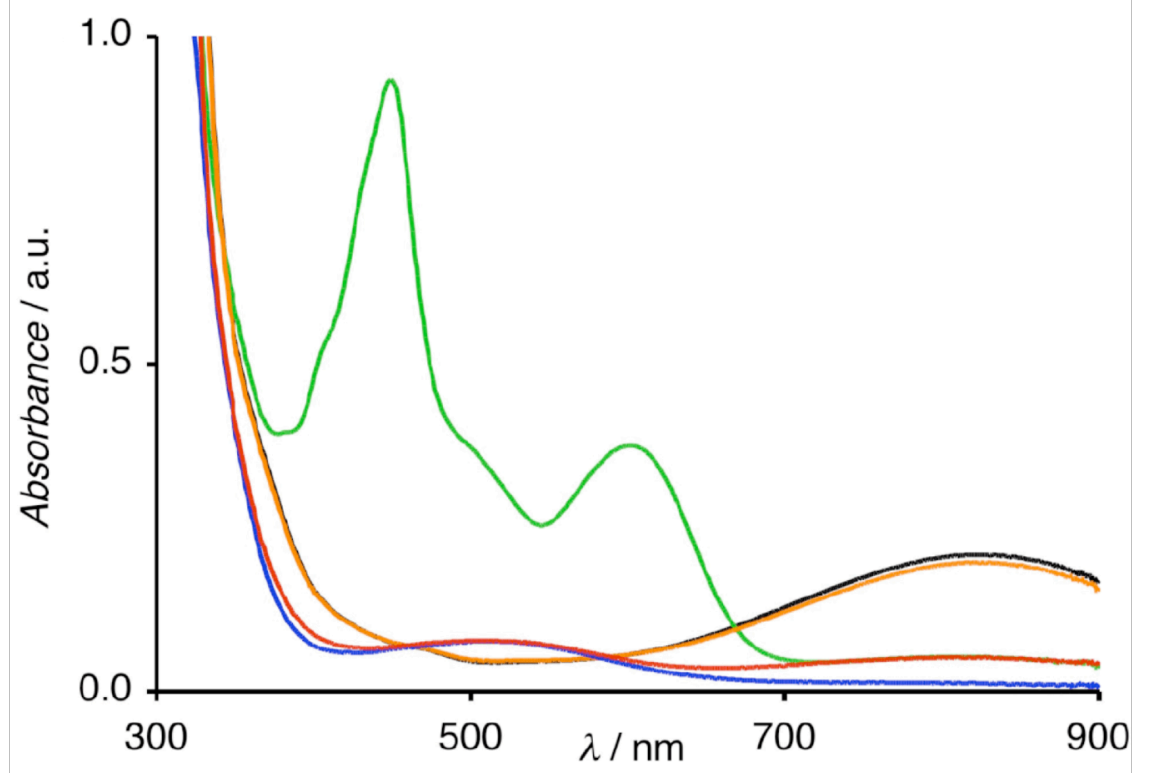

Figure S9. Absorption spectral changes observed upon electrochemical oxidation of rotaxane $\mathbf{4}^{4+}$ in DMF. Conditions: $1.0 \times 10^{-3} \mathrm{M}, \mathrm{TBAPF}_{6} 0.1 \mathrm{M}$, optical path length $1 \mathrm{~mm}$. Black trace: initial spectrum. Green trace: after electrolysis at $+0.62 \mathrm{~V}$ (vs Ag pseudo-reference electrode) corresponding to complete oxidation of the TTF station to the $\mathrm{TTF}^{+}$state. Subsequent exhaustive electrolysis at $-0.2 \mathrm{~V}$ regenerates the original spectrum (orange trace). Blue trace: after electrolysis at $+1.1 \mathrm{~V}$ corresponding to complete oxidation of the TTF station to the $\mathrm{TTF}^{2+}$ state. Subsequent electrolysis at $-0.2 \mathrm{~V}$ does not regenerate the original spectrum (red trace).

The absorption changes observed upon electrochemical oxidation of rotaxane $4^{4+}$ in DMF are reported in Figure S9. Application of a potential of $+0.62 \mathrm{~V}$ leads to full monoelectronic oxidation of the TTF unit, as indicated by the appearance of the typical absorption bands of the $\mathrm{TTF}^{+}$form (see Figure S8), and the parallel disappearance of the $\mathrm{TTF}^{-\mathrm{CBPQT}}{ }^{4+} \mathrm{CT}$ band at $830 \mathrm{~nm}$ (Figure S9, green trace). The expected displacement of the $\mathrm{CBPQT}^{4+}$ ring on the DNP station, however, cannot be evidenced because the weak DNP-CBPQT ${ }^{4+}$ CT band would be hidden by the more intense $\mathrm{TTF}^{+}$bands. These changes are almost fully reversed upon successive back electrolysis at $-0.2 \mathrm{~V}$ (orange trace), showing the reversibility of the first monoelectronic oxidation process. Electrolysis at $+1.1 \mathrm{~V}$ affords complete oxidation of the TTF moiety to the dicationic form (blue trace). At this point not only the TTF-CBPQT ${ }^{4+}$ band has disappeared, but the $\mathrm{DNP}-\mathrm{CBPQT}^{4+} \mathrm{CT}$ band shows up clearly at $520 \mathrm{~nm}$, indicating that the ring has moved on the DNP station. Subsequent electrolysis at $-0.2 \mathrm{~V}$ does not regenerate the starting 
spectrum (red trace) because the $\mathrm{TTF}^{2+}$ species undergoes a chemical reaction in DMF, as observed for the TTF model 19 (Figure S8).

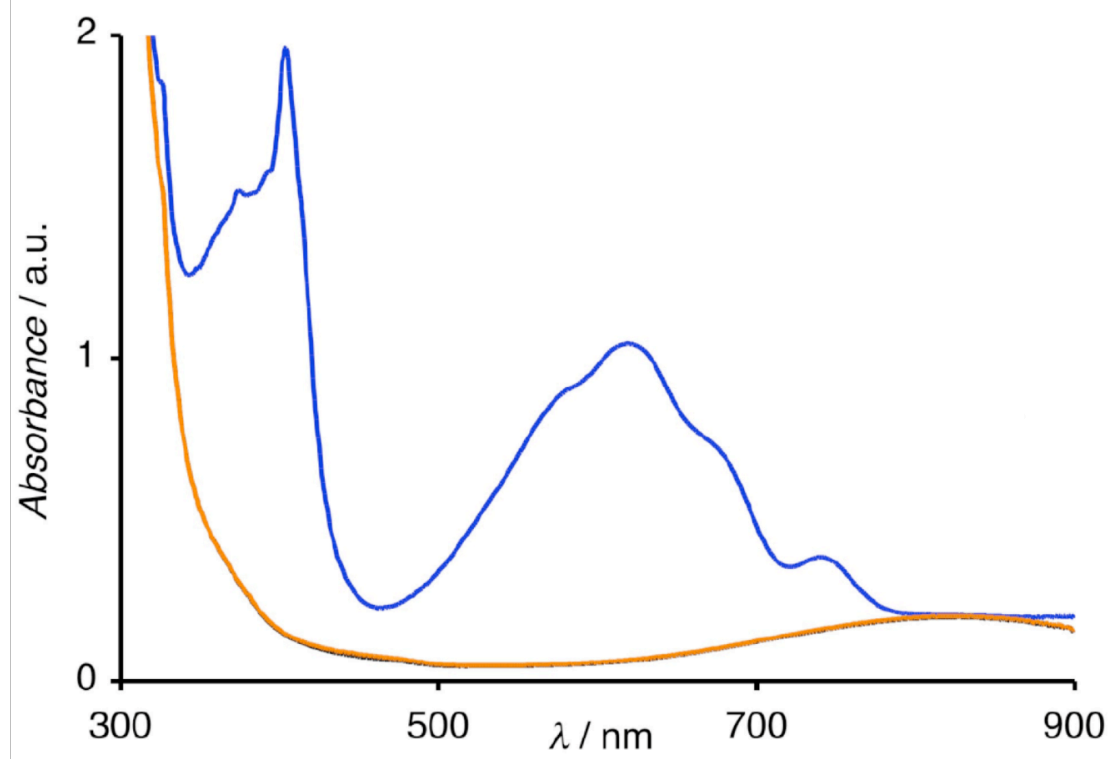

Figure S10. Absorption spectral changes observed upon electrochemical reduction of rotaxane $4^{4+}$ in DMF. Conditions: $1.0 \times 10^{-3} \mathrm{M}, \mathrm{TBAPF}_{6} 0.1 \mathrm{M}$, optical path length $1 \mathrm{~mm}$. Black trace: initial spectrum. Blue trace: after exhaustive electrolysis at $-0.3 \mathrm{~V}$ (vs $\mathrm{Ag}$ pseudo-reference electrode) corresponding to reduction of the $\mathrm{CBPQT}^{4+}$ component to the $\mathrm{CBPQT}^{2+}$ state. Subsequent electrolysis at $+0.2 \mathrm{~V}$ regenerates the original spectrum (orange trace, superimposed with the black trace).

Upon electrochemical reduction of $\mathbf{4}^{4+}$ at $-0.3 \mathrm{~V}$, absorption changes corresponding to the complete monoelectronic reduction of the bipyridinium units of the ring are observed (Figure S10, blue trace). The appearance of an absorption tail in the $750-900 \mathrm{~nm}$ region prevents a clear evaluation of the changes in the CT band at $830 \mathrm{~nm}$. Back electrolysis at $0 \mathrm{~V}$ causes the disappearance of the bands characteristic of the reduced bipyridinium units and the original spectrum is restored (orange trace), showing the full reversibility of this process. 
Chemical switching. Another means for triggering switching in TTF-DNP bistable systems consists in the use of chemical oxidants and reductants for controlling the reversible interconversion of the different oxidation states of the TTF unit. For this purpose, $\mathrm{Fe}(\mathrm{III})$ perchlorate and ascorbic acid have been typically used (see e.g. refs. 14, $17,31,32)$ as the oxidant and reductant, respectively.
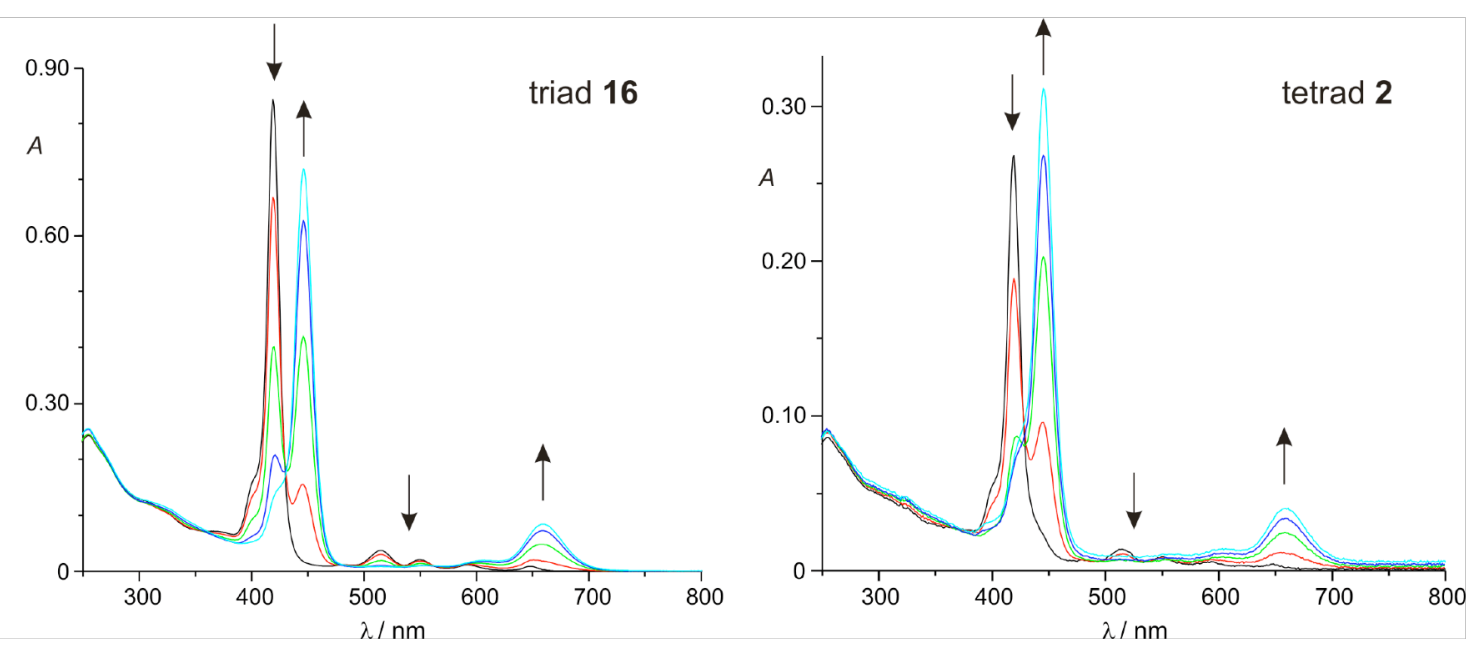

Figure S11. Absorption spectral changes observed upon titration of triad $\mathbf{1 6}\left(3.0 \times 10^{-6} \mathrm{M}\right.$, left $)$ and tetrad $2\left(1.9 \times 10^{-6} \mathrm{M}\right.$, right $)$ with $\mathrm{Fe}\left(\mathrm{ClO}_{4}\right)_{3}$ in THF. Black trace: 0 equiv; red trace, 0.25 equiv; green trace, 0.50 equiv; blue trace, 0.75 equiv; cyan trace, 1.0 equiv. The addition of more $\mathrm{Fe}\left(\mathrm{ClO}_{4}\right)_{3}$ (up to 2 equiv) does not cause further spectral changes.

Since the electrochemical switching of $\mathbf{1}^{4+}$ proved to be poorly efficient, we tried to oxidize the TTF station chemically. Specifically, we attempted oxidation of the TTF unit of triad 16, tetrad 2, and rotaxane $\mathbf{1}^{4+}$ with $\mathrm{Fe}\left(\mathrm{ClO}_{4}\right)_{3}$. Titration of triad $\mathbf{1 6}$ and tetrad 2 with the oxidant in THF leads (Figure S11) to strong spectral changes, involving mostly the porphyrin bands, that are completed after 1 equiv of $\mathrm{Fe}^{3+}$. Specifically, the strong Soret band is red-shifted by ca. $30 \mathrm{~nm}$, the Q-bands in the $500-620 \mathrm{~nm}$ region decrease in intensity, and a new band at $660 \mathrm{~nm}$ shows up. The spectral changes observed do not correspond to oxidation of the TTF unit, which would have caused an increase of absorbance in the $500-650 \mathrm{~nm}$ region; rather, they are fully consistent ${ }^{\mathrm{S11}}$ with the protonation of the free-base porphyrin unit. This conclusion is in line with the fact that the same behavior is exhibited by the porphyrin model 20. To our surprise, no evidence 
of TTF oxidation was observed even after addition of an excess of oxidant. A likely explanation is that the $\mathrm{Fe}^{3+}$ ions, together with water molecules present both in the perchlorate salt and as solvent impurities, give rise to hydroxo complexes ${ }^{\mathrm{S} 12}$ that are capable of protonating the porphyrin unit in THF. This process does not occur in DMF, as shown by experiments on porphyrin $\mathbf{2 0}$, probably because of coordination of $\mathrm{Fe}^{3+}$ ions by DMF molecules via their amidic group.

Addition of 1 equiv of $\mathrm{Fe}\left(\mathrm{ClO}_{4}\right)_{3}$ to either the TTF model 19 or rotaxane $4^{4+}$ in MeCN leads, as expected, to the quantitative one-electron oxidation of the TTF station and, in the case of $\mathbf{4}^{4+}$, to the concomitant disappearance of the CT band at $830 \mathrm{~nm}$. When we performed the same experiments in DMF, we could not observe spectral changes attributable to oxidation of the TTF unit. As noted above, it is likely that $\mathrm{Fe}^{3+}$ ions are stabilized by DMF coordination and therefore loose their oxidizing ability. Similar results were observed on titration of $\mathbf{1}^{4+}$ with $\mathrm{Fe}\left(\mathrm{ClO}_{4}\right)_{3}$ in $\mathrm{DMF}$, indicating that no oxidation of the rotaxane takes place under these conditions.
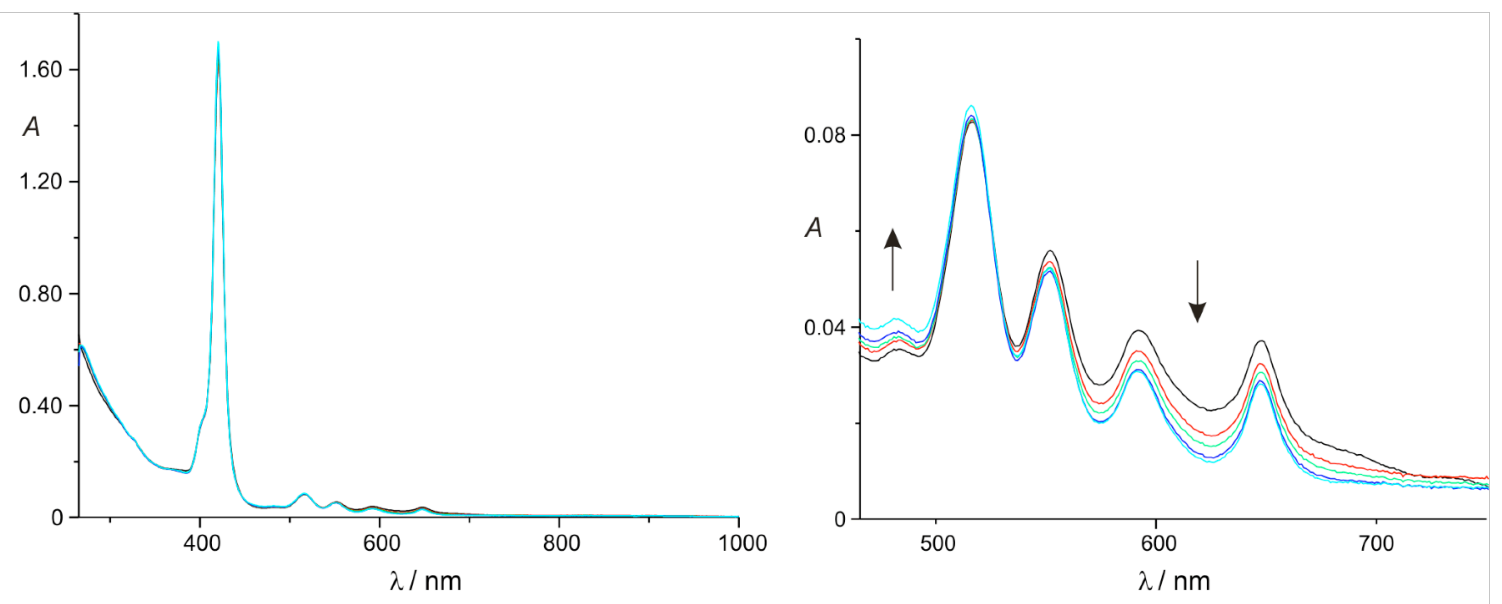

Figure S12. Absorption spectral changes (left, overall view; right, detail of the $480-750 \mathrm{~nm}$ region) observed upon titration of a $4.0 \times 10^{-6} \mathrm{M} \mathrm{DMF}$ solution of rotaxane $\mathbf{1}^{4+}$ with $\mathrm{Fe}\left(\mathrm{ClO}_{4}\right)_{3}$. The addition of more $\mathrm{Fe}\left(\mathrm{ClO}_{4}\right)_{3}$ (up to 2 equiv) does not cause further spectral changes.

The titration of rotaxane $\mathbf{1}^{4+}$ with $\mathrm{Fe}\left(\mathrm{ClO}_{4}\right)_{3}$ in DMF causes very small spectral changes (Figure S12) which again are inconsistent with the oxidation of the TTF station. The formation of the $\mathrm{TTF}^{+}$unit would cause an increase in absorbance in the 550-650 nm 
region, whereas the absorbance decreases in such region upon titration with the oxidant. The small changes in the porphyrin Q-bands can be assigned to the interaction of the $\mathrm{P}$ unit with the perchlorate anions of the oxidizing agent. Protonation of the porphyrin unit is not observed, in contrast with the experiments performed in THF (Figure S11), most likely because the reactivity of $\mathrm{Fe}^{3+}$ ions is very different in the two solvents, as discussed above.

Attempts of using $\mathrm{NOBF}_{4}$ as an alternative oxidant for $\mathbf{1 9}, \mathbf{4}^{4+}$ and $\mathbf{1}^{4+}$ in DMF also failed. No further investigations were performed on account of the lack of solubility of $\mathbf{1}^{4+}$ in solvents other than DMF.

\section{Reference:}

S1. (a) Saha, S.; Johansson, L. E.; Flood, A. H.; Tseng, H.-R.; Zink, J. I.; Stoddart, J. F. Small, 2005, 1, 87-90. (b) Saha, S.; Johansson, E.; Flood, A. H.; Tseng, H. R.; Zink, J. I.; Stoddart, J. F. Chem. Eur. J. 2005, 11, 6846-6858.

S2. (a) Khalil, B.; Calinaud, P.; Gelas, J.; Ghobsi, M. Carb. Res. 1994, 264, 33-44. (b) Xie, H.; Wu, S. Supramol. Chem. 2001, 13, 546-556.

S3. Becher, J.; Matthews, O.; Nielsen, K.; Mogens, B.; Raymo, F. M.; Stoddart, J. F. Synlett 1999, 330-332.

S4. Tseng, H.-R.; Vignon, S. A.; Celestre, P. C.; Perkins, J.; Jeppesen, J. O.; Di Fabio, A.; Ballardini, R.; Gandolfi, M. T.; Venturi, M.; Balzani, V.; Stoddart, J. F. Chem. Eur. J. 2004, $10,155-172$.

S5. Roth, B.; Baccanari, D. P.; Sigel, C. W.; Hubbell, J. P.; Eaddy, J.; Kao, J. C.; Grace, M. E.; Rauckman, B. S. J. Med. Chem. 1988, 31, 122-129.

S6. Anelli, P.-L.; Ashton, P. R.; Ballardini, R.; Balzani, V.; Delgado, M.; Gandolfi, M. T; Goodnow, T. T.; Kaifer, A .E.; Philp, D.; Pietrazkiewicz, M.; Prodi, L.; Reddington, M. V.; Slawin, A. M. Z.; Spencer, N.; Stoddart, J. F.; Vincent, C.; Williams, D. J. J. Am. Chem. Soc. 1992, 114, 193-218. 
S7. Noviandri, I.; Brown, K. N.; Fleming, D. S.; Gulyas, P. T.; Lay, P. A.; Masters, A. F.; Phillips, L. J. Phys. Chem. B 1999, 103, 6713-6722.

S8. Krejčik, M.; Daněk, M.; Hartl, F. J. Electroanal. Chem. 1991, 317, 179-187.

S9. Flanagan, J.B.; Margel, S.; Bard, A.J.; Anson, F.C. J. Am. Chem. Soc. 1978, 100, 42484253.

S10. Sandanayaka, A.S.D.; Araki, Y.; Ito, O.; Deviprasad, G.R.; Smith, P.M.; Rogers, L.M.; Zandler, M.E.; D’Souza, F. Chem. Phys. 2006, 325, 452-460.

S11. Finikova, O.; Galkin, A.; Rozhkov, V.; Cordero, M.; Hägerhäll, C.; Vinogradov, C. J. Am. Chem. Soc. 2003, 125, 4882-4893.

S12. Lopes, L.; de Laat, J.; Legube, B. Inorg. Chem. 2002, 41, 2505-2517.

\section{Complete References:}

17. (a) Anelli, P.-L.; Asakawa, M.; Ashton, P. R.; Bissell, R. A.; Clavier, G.; Górski, R.; Kaifer, A. E.; Langford, S. J.; Mattersteig, G.; Menzer, S.; Philp, D.; Slawin, A. M. Z.; Spencer, N.; Stoddart, J. F.; Tolley, M. S.; Williams, D. J. Chem. Eur. J. 1997, 3, 11361150 .

25. (b) Ashton, P. R.; Ballardini, R.; Balzani, V.; Boyd, S. E.; Credi, A.; Gandolfi, M. T.; Gómez-López, M.; Iqbal, S.; Philp, D.; Preece, J. A.; Prodi, L.; Ricketts, H. G.; Stoddart, J. F.; Tolley, M. S.; Venturi, M.; White, A. J. P.; Williams, D. J. Chem. Eur. J. 1997, 3, 152170.

38. (a) Anelli, P.-L.; Ashton, P. R.; Ballardini, R.; Balzani, V.; Delgado, M.; Gandolfi, M. T; Goodnow, T. T.; Kaifer, A .E.; Philp, D.; Pietrazkiewicz, M.; Prodi, L.; Reddington, M. V.; Slawin, A. M. Z.; Spencer, N.; Stoddart, J. F.; Vincent, C.; Williams, D. J. J. Am. Chem. Soc. 1992, 114, 193-218. 
